\title{
Glucosinolate Profiling and Expression Analysis of Glucosinolate Biosynthesis Genes Differentiate White Mold Resistant and Susceptible Cabbage Lines
}

\author{
Md. Abuyusuf ${ }^{1}$, Arif Hasan Khan Robin ${ }^{1,2}{ }^{\circledR}$, Ji-Hee Lee ${ }^{1}$, Hee-Jeong Jung ${ }^{1}$, Hoy-Taek Kim ${ }^{1}$, \\ Jong-In Park ${ }^{1, *}$ and Ill-Sup Nou ${ }^{1, *}$ \\ 1 Department of Horticulture, Sunchon National University, 255 Jungang-ro, Suncheon, Jeonnam 57922, Korea; \\ yusuf_agr@pstu.ac.bd (M.A.); gpb21bau@gmail.com (A.H.K.R.); jihee0830@scnu.ac.kr (J.-H.L.); \\ gml79wjd@sunchon.ac.kr (H.-J.J.); htkim@sunchon.ac.kr (H.-T.K.) \\ 2 Department of Genetics and Plant Breeding, Bangladesh Agricultural University, \\ Mymensingh 2202, Bangladesh \\ * Correspondence: jipark@sunchon.ac.kr (J.-I.P.); nis@sunchon.ac.kr (I.-S.N.); Tel.: +82-61-750-3241 (J.-I.P.); \\ +82-61-750-3249 (I.-S.N.); Fax: +82-61-750-3208 (J.-I.P.); +82-61-750-5389 (I.-S.N.)
}

Received: 24 October 2018; Accepted: 11 December 2018; Published: 13 December 2018

\begin{abstract}
Sclerotinia stem rot (white mold), caused by the fungus Sclerotinia sclerotiorum, is a serious disease of Brassica crops worldwide. Despite considerable progress in investigating plant defense mechanisms against this pathogen, which have revealed the involvement of glucosinolates, the host-pathogen interaction between cabbage (Brassica oleracea) and S. sclerotiorum has not been fully explored. Here, we investigated glucosinolate profiles and the expression of glucosinolate biosynthesis genes in white-mold-resistant $(\mathrm{R})$ and -susceptible $(\mathrm{S})$ lines of cabbage after infection with S. sclerotiorum. The simultaneous rise in the levels of the aliphatic glucosinate glucoiberverin (GIV) and the indolic glucosinate glucobrassicin (GBS) was linked to white mold resistance in cabbage. Principal component analysis showed close association between fungal treatment and cabbage GIV and GBS contents. The correlation analysis showed significant positive associations between GIV content and expression of the glucosinolate biosynthesis genes ST5b-Bol026202 and ST5c-Bol030757, and between GBS content and the expression of the glucosinolate biosynthesis genes ST5a-Bol026200 and ST5a-Bol039395. Our results revealed that S. sclerotiorum infection of cabbage induces the expression of glucosinolate biosynthesis genes, altering the content of individual glucosinolates. This relationship between the expression of glucosinolate biosynthesis genes and accumulation of the corresponding glucosinolates and resistance to white mold extends the molecular understanding of glucosinolate-negotiated defense against $S$. sclerotiorum in cabbage.
\end{abstract}

Keywords: white mold; Sclerotinia sclerotiorum; glucosinolates; R line; S line; cabbage

\section{Introduction}

White mold caused by the fungal pathogen Sclerotinia sclerotiorum infects more than 400 plant species, including important crops such as sunflower, chickpea and rapeseed [1,2]. The pathogen usually infects plants as mycelia or airborne ascospores [3]. Although a few fungicides are available to manage this disease, their low efficiencies, the environmental contamination they cause, and the economic costs of both the treatments and the disease itself are substantial [4]. Thus, breeding resistant varieties is the best strategy to control this disease [5]. Although the wide genetic diversity of the members of the Brassicaceae family makes it difficult to draw concrete conclusions, it is generally believed that resistance against S. sclerotiorum exists primarily in Brassica napus and its relatives [6]. Some efforts have been made to identify resistance resources from wild crucifers, such as Erucastrum 
cardaminoides and Erucastrum abyssinicum [7], Erucastrum gallicum [8], and Capsella bursa-pastoris [9]. More recently, scientists have identified resources with high levels of resistance against $S$. sclerotiorum from wild Brassica oleracea [10], one of the parental species of rapeseed. This finding brings new hope for improving S. sclerotiorum resistance of rapeseed, especially since its wild relatives, such as Brassica rupestris, Brassica incana, Brassica insularis, and Brassica villosa, show high levels of resistance [10]. Completely or highly resistant lines of $B$. oleracea are not currently available. The lack of a resistance source has greatly constrained the breeding of B. oleracea for $S$. sclerotiorum resistance, so that little practical benefit has accrued to date from research on S. sclerotiorum resistance in B. oleracea. Moreover, the interactions between B. oleracea and S. sclerotiorum leading to eventual pathogenesis have received little attention. Resistance genes and secondary metabolites involved in plant-pathogen interactions provide general resistance to pathogens and insects [11-14]. In Brassicaceae, glucosinolates (GSLs), vital secondary metabolites biosynthesized from amino acids that are perhaps best known for their anti-oxidative and anti-carcinogenic roles in humans, play important functional roles in the plants' own resistance to pathogens and insects. GSL metabolism is thus a potentially fruitful source of pathogen-resistance genes.

GSLs can be grouped into three different classes according to the amino acid(s) from which they are derived: aliphatic/alkenyl glucosinolates, derived from methionine; aromatic glucosinolates, derived from phenylalanine and tyrosine; and indole glucosinolates, derived from tryptophan [11]. Among the three classes, aliphatic and indole GSLs are the two most important in Brassicaceae [15-17]. GSLs and their hydrolyzed products show significant antimicrobial and insecticidal activities [18] as well as anti-fungal properties in plants [19-26]. GSLs are the precursors of sulfur- and nitrogen-containing secondary metabolites such as isothiocyanates and sulforaphane [27-30]. The effects of GSL metabolism and sulfur and nitrogen nutrition have been studied because Brassica crops contain large amounts of sulfur-containing amino acids and GSLs [31-34]. In a study on the antimicrobial effect of crude extracts from Arabidopsis thaliana [23], 4-methylsulfonyl butyl isothiocyanate was found to be the main active compound, with broad antimicrobial activity, which implied that this GSL-derived isothiocyanate might have a protective effect against plant pathogens. Several investigations revealed alterations of GSL profile upon fungal inoculation [35-38]. Initial reports described only alteration of indole GSLs [37], but more recent studies have reported alteration of both aliphatic and indole GSLs in response to fungal pathogens [36,38]. Anti-oxidative compounds produced from the degradation of GSLs bring about plants' defense response against pathogens and herbivores [24,39]. Biotic and abiotic factors, such as pathogen infection, herbivore damage, mechanical injury, and mineral nutrition, can modulate the GSL profile [40-42]. Moreover, a wide range of defense reactions can affect GSL content [22,42-44].

However, an association between GSL levels and resistance to various fungal pathogens in brassicas has not yet been established [36]. In fact, studies in various Brassica species have repeatedly failed to find a strong correlation between pathogen resistance and GSL content following fungal infection, so the overall scenario is perplexing [45,46]. In Arabidopsis, the MAM1 mutant showed a decrease in GSL level that resulted in susceptibility to Fusarium oxysporum, pointing to a protective role of GSLs against fungal infection [23]. GSL levels are also positively correlated with oilseed rape resistance to the pathogen Sclerotinia sclerotiorum [47,48], with a few exceptions [43,49-52]. However, high GSL levels enhance Arabidopsis susceptibility to the fungus Alternaria brassicicola [52]. A negative correlation between GSL content in Brassica napus and resistance to strains of $A$. brassicicola and Alternaria brassicae has also been observed [49]. The inconsistency of the existing data may reflect variations in the behavior of individual fungi (e.g., necrotrophs versus biotrophs) [53], their host specificity (e.g., Brassica specialist versus broad spectrum) [54], the genetic purity of the host plants (e.g., isogenic versus heterozygous lines), and the amounts of GSLs and their degradation products produced by the host plant. In cabbage (B. oleracea), the relationship between GSL content and resistance to $S$. sclerotiorum has not yet been studied. Several recent reports have shown that resistance to obligate biotrophs, hemibiotrophs, and necrotrophs might be linked to the production of indole 
GSLs in Brassicaceae $[55,56]$. Moreover, in B. oleracea in particular, the enhanced accumulation of certain aliphatic and indole GSL compounds is associated with concomitant increases in the expression of GSL biosynthesis genes in several inbred lines [35-37,57]. These findings on the association of resistance with the GSL profile of Brassica species prompted us to examine these plant-pathogen interactions at the molecular and biochemical level. Here, we investigated the correlation between GSL profiles in resistant and susceptible cabbage lines, and the expression of GSL biosynthesis genes upon infection with S. sclerotiorum.

\section{Results}

\subsection{Resistance of Different Cabbage Lines to S. sclerotiorum}

We inoculated cabbage leaves of 45 inbred lines of cabbage with S. sclerotiorum and observed noteworthy differences in response in terms of the appearance of disease symptoms. In particular, one line, SCNU-C-049 (denoted hereafter as the resistant or R line), exhibited complete resistance with no disease symptoms, while the other 44 lines were susceptible to $S$. sclerotiorum, as evidenced by changes visible at 5 days post inoculation (DPI) (Supplementary File S1). We confirmed the resistance of SCNU-C-049 and the susceptibility of one selected S line (SCNU-C-033) through three repeated experiments, in which infected leaf, stem and head of both the $\mathrm{R}$ line and the selected $\mathrm{S}$ line showed consistent disease reactions (Figure 1).

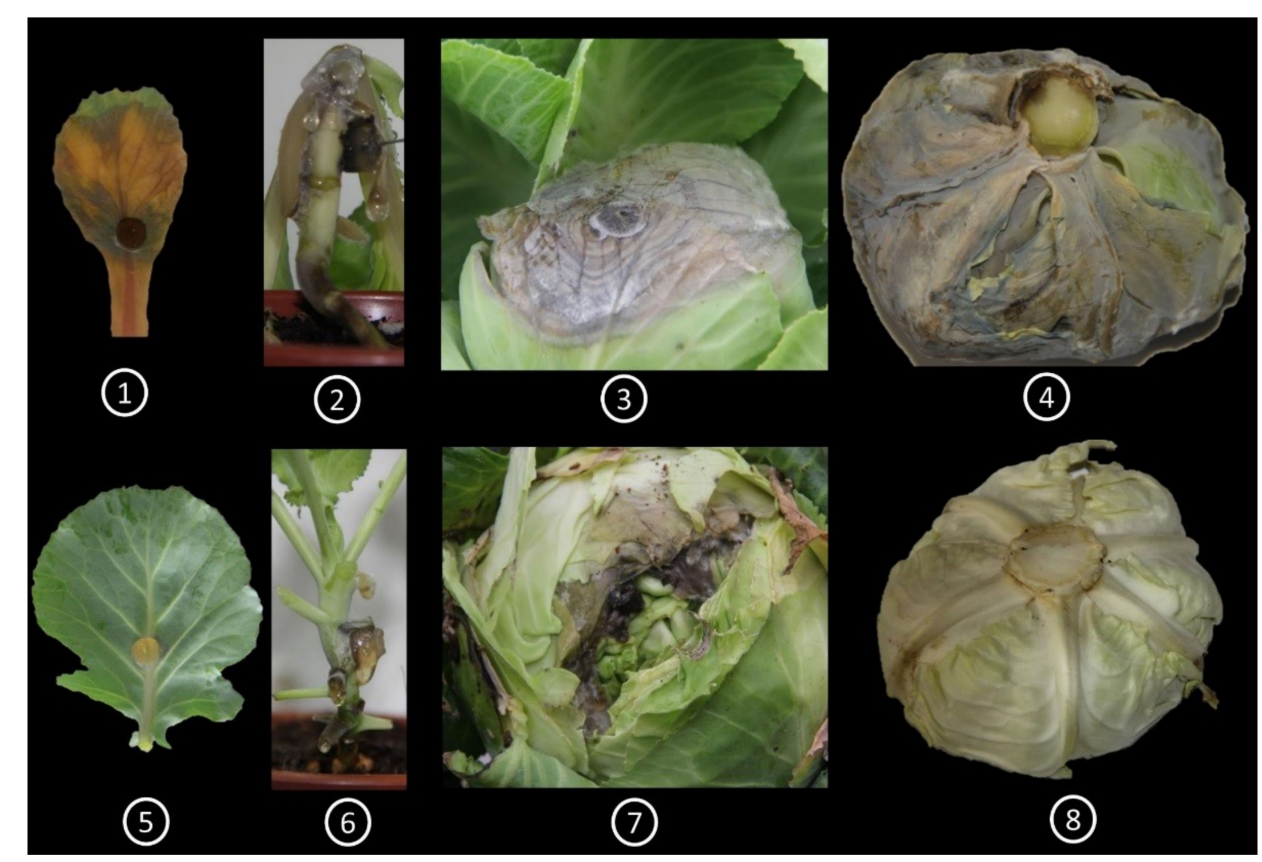

Figure 1. Leaf, stem and head bioassay of the susceptible line SCNU-C-033 (1, leaf; 2, stem; 3, head seen from top; $\mathbf{4}$, head seen from bottom) and resistant line SCNU-C-049 (5, leaf; 6, stem; 7, head seen from top; 8 , head seen from bottom) of cabbage inoculated with $S$. sclerotiorum. Photographs were taken on the following days post inoculation (DPI): leaf, 5 DPI; stem, 7 DPI; head from top, 10 DPI; head from bottom, 15 DPI.

\subsection{Overview of Individual GSL Profiles in Cabbage Lines}

Another study conducted by our group had previously produced a sample illustrative spectrum by mass spectrometry analysis of samples from cabbage lines that were resistant and susceptible to a different pathogen, ringspot (Mycosphaerella brassicicola), and used it to identify individual glucosinolate compounds found in cabbage leaves [38]. We performed high-performance liquid chromatography (HPLC) analysis to detect eleven GSL compounds identified in that earlier work in our R (SCNU-C-049) 
and S (SCNU-C-033) cabbage lines: glucoiberin (GIB), progoitrin (PRO), glucoraphanin (GRA), sinigrin (SIN), glucoerucin (GER), gluconapin (GNA), glucoiberverin (GIV), hydroxyglucobrassicin (HGBS), glucobrassicin (GBS), methoxyglucobrassicin (MGBS), and neoglucobrassicin (NGBS) (see HPLC peaks and GSL contents in Supplementary File S2 and Supplementary File S3). In non-inoculated control plants, the amounts of both aliphatic and indole GSLs (i.e., PRO, GRA, MGBS, and GBS) differed significantly from those in the inoculated $\mathrm{R}$ and $\mathrm{S}$ plants (Figure 2). Inoculating cabbage plants with S. sclerotiorum significantly changed the GSL profiles in the leaves of both the R and S lines. In the R line, the level of GIV was significantly higher, by 1.46-fold, in inoculated plants at 3 DPI, compared to that in mock-treated plants (Figure 2). In contrast, the GIV level was not significantly altered after fungal infection in the S line (Figure 2, Table S1). Similarly, the level of GBS in the R line was 5.28-fold higher in the treated compared to the mock-treated plants at 3 DPI (Figure 2, Table S1), whereas the $\mathrm{S}$ line did not show significant changes in GBS level after infection. Thus, GIV and GBS showed an increasing trend after infection only in the $\mathrm{R}$ line.

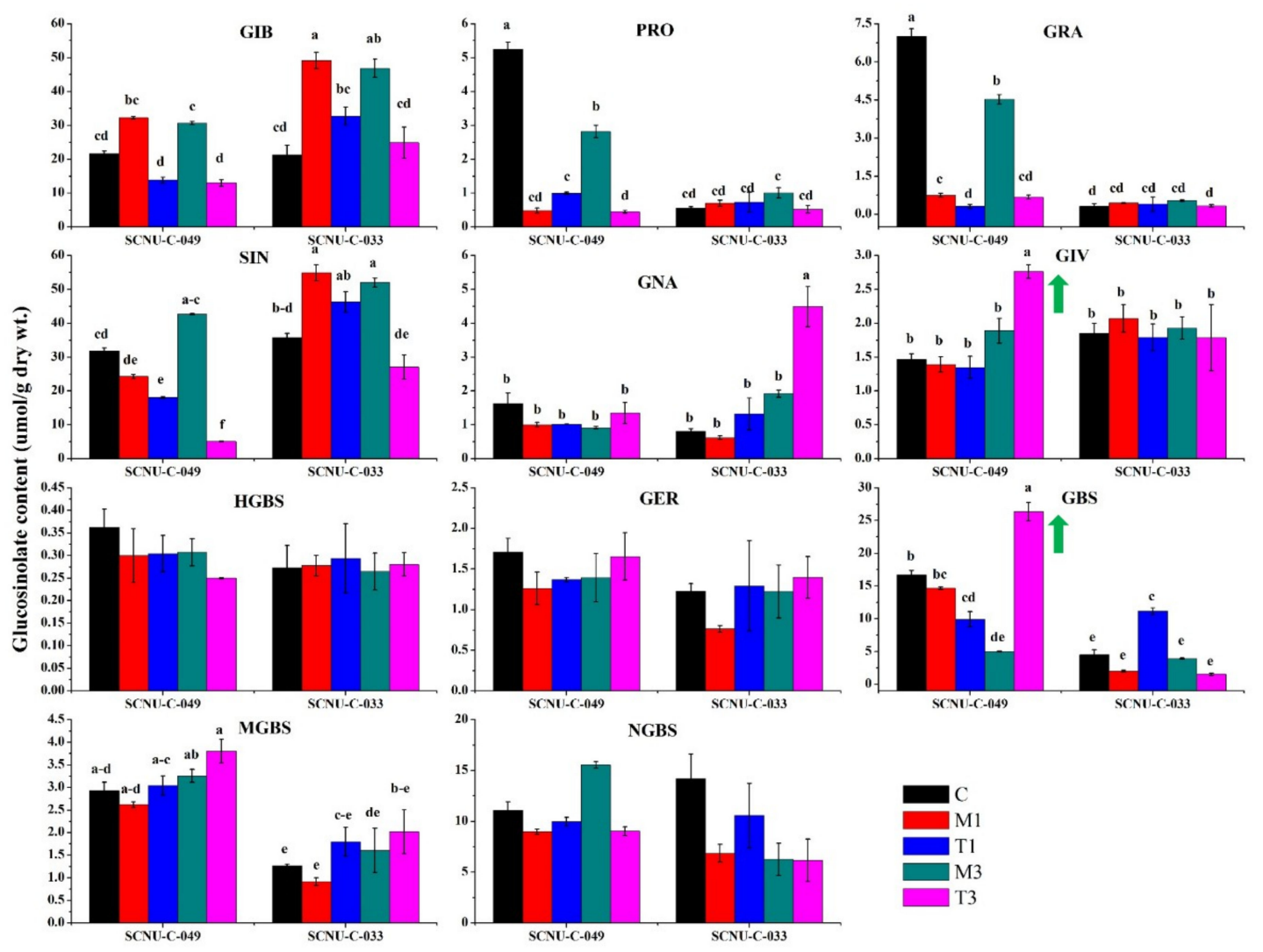

Figure 2. Contents of 11 individual glucosinolates in leaf samples from R (SCNU-C-049) and S (SCNU-C-033) lines of cabbage under different treatment conditions (C, control; M1, mock day 1; T1, treated day 1; M3, mock day 3; T3, treated day 3). The means of three biological replicates are presented. Vertical bars indicate standard deviation. Different letters indicate statistically significant differences between $\mathrm{R}$ and $\mathrm{S}$ lines and treatment interactions. Upward-pointing green arrows indicate increased glucosinolate content of $\mathrm{R}$ line in response to S. sclerotiorum infection. R, resistant; S, susceptible. HPLC-mass spectrometry (HPLC-MS) analysis (using an Agilent 1200 series instrument, Agilent Technologies) was conducted following Abuyusuf et al. [38].

In the S line, the levels of GNA were significantly higher, by 2.34-fold, at 3 DPI in the treated compared to the mock-treated plants, whereas the GNA level was not significantly altered in the $\mathrm{R}$ line after infection (Figure 2, Table S1). Overall, our results showed that the contents of both aliphatic GIV and indole GBS increased in the R line, but not the $S$ line, starting at the time of infection (Figure 2). In addition, the total GSL content did not vary significantly in either the R or the S line at 3 DPI (Figure S1). 
2.3. Upregulation of MYB28-Bol017019, MYB34-Bol017062, ST5a-Bol026200, ST5a-Bol039395, ST5b-Bol026202 and ST5c-Bol030757 in the R Line after Inoculation

In order to investigate whether the expression levels of genes belonging to the aliphatic and indole GSL biosynthesis pathways, and their associated transcription factors, are associated with plant resistance upon S. sclerotionum infection, reverse transcription quantitative PCR (RT-qPCR) was performed. The Actin gene (actin1) was used for normalization of expression of 38 target genes. The expression levels and melting curves of the Actin gene and 38 glucosinolate-biosynthesis-related genes are given in Supplementary File S3 and Supplementary File S4, respectively. The forward and reverse primers of Actin1 were designed based on the sequence available at NCBI database (GenBankAccession no. AF044573). The selection of that gene as reference gene to perform expression data normalization was based on previous reports showing the stability of that gene in the same plant species upon similar experimental conditions $[35,58]$. Here we report the changes in the transcription levels of genes encoding aliphatic and indole GSL biosynthesis and their associated transcription factors that resulted from S. sclerotiorum infection. We found that two genes encoding transcription factors-one affecting the synthesis of an aliphatic GSL, MYB28-Bol017019, and one that of an indole GSL, MYB34-Bol017062-showed 10.21-fold and 3.08-fold upregulation at 1 DPI in the R line after infection, respectively, as compared to their expression in mock-treated plants (Figure 3, Table 1, and Table S2). Two aliphatic biosynthesis genes, ST5b-Bol026202 and ST5c-Bol030757, and two indole biosynthesis genes, ST5a-Bol026200 and ST5a-Bol039395, were also significantly upregulated in the R line at 3 DPI: ST5b-Bol026202 and ST5c-Bol030757 exhibited 5.6-fold and 68.59-fold upregulation, whereas ST5a-Bol026200 and ST5a-Bol039395 exhibited 82.90-fold and 25.30-fold upregulation, respectively (Figure 3, Table 1, and Tables S3 and S4).

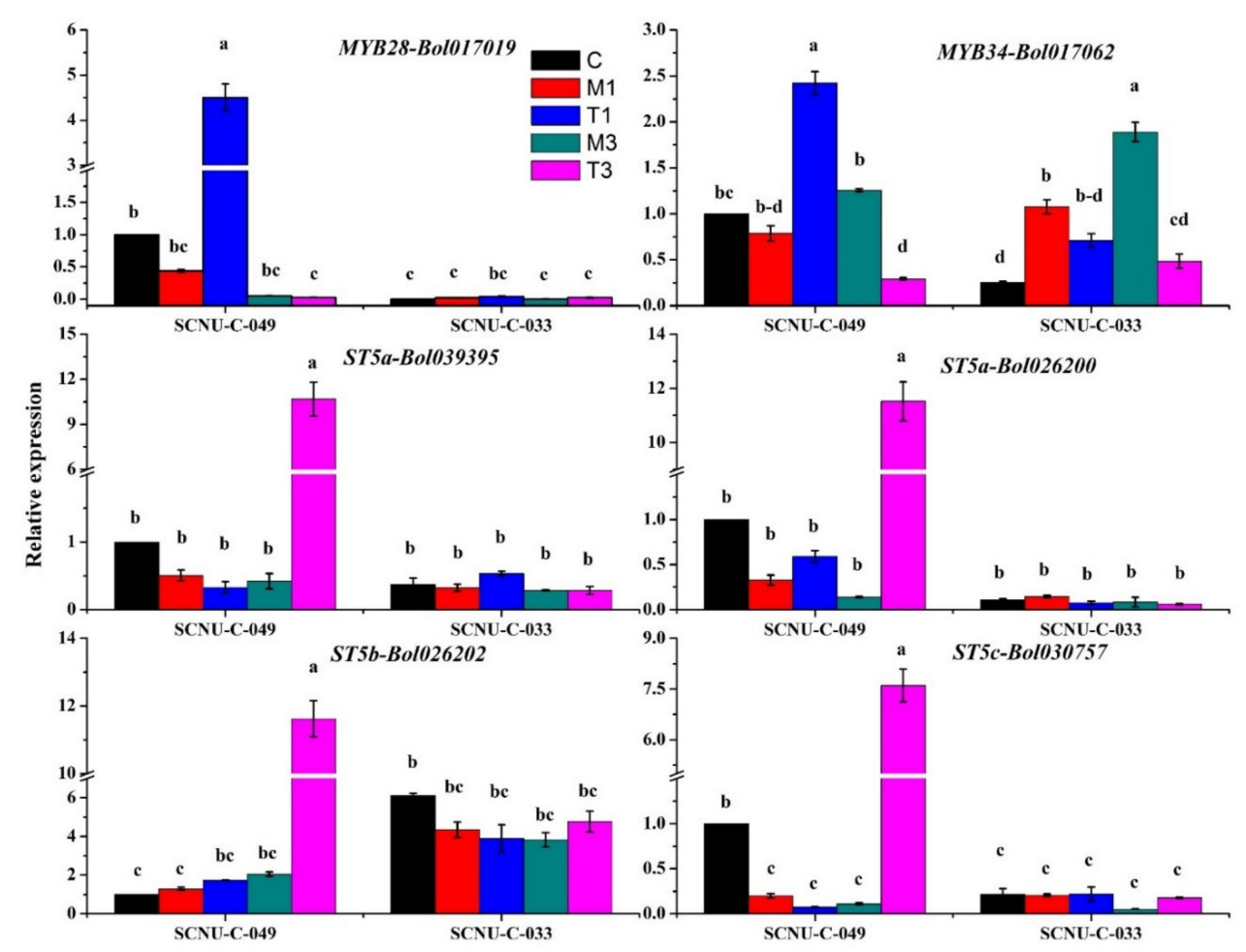

Figure 3. Upregulation of MYB28-Bol017019, MYB34-Bol017062, ST5a-Bol026200, ST5a-Bol039395, ST5b-Bol026202 and ST5c-Bol030757 genes in white-mold-inoculated R (SCNU-C-049) line at 1 and 3 DPI compared to mock-treated plants. No similar upregulation was seen in a susceptible (S; SCNU-C-033) line. C, control; M1, mock day 1; T1, treated day 1; M3, mock day 3; T3, treated day 3. The means of three biological replicates are presented. Vertical bars indicate standard deviation. Different letters indicate statistically significant differences between $\mathrm{R}$ and $\mathrm{S}$ lines and treatment interactions. $\mathrm{R}$, resistant; S, susceptible. 
Table 1. Differential expression of genes related to the glucosinolate biosynthesis pathway in white-mold-inoculated R and $S$ cabbage. Numbers in blue and purple color letter indicate days at which genes were expressed and fold differences compare to mock-treated plants, respectively. R, resistant (SCNU-C-049); S, susceptible (SCNU-C-033).

\begin{tabular}{|c|c|c|c|c|}
\hline \multirow{2}{*}{ Function of Gene Product } & \multirow{2}{*}{ Genes Upregulated in R Line } & \multirow{2}{*}{ Genes Upregulated in S Line } & \multicolumn{2}{|c|}{ Genes Upregulated in both $\mathrm{R}$ and $\mathrm{S}$ Lines } \\
\hline & & & Higher in $\mathrm{R}$ Line & Higher in S Line \\
\hline Transcription Factor & $\begin{array}{l}\text { MYB28-Bol017019 }(1,10.2) \\
\text { MYB34-Bol017062 }(1,3.08)\end{array}$ & $\begin{array}{l}\text { MYB28-Bol036743 }(1,5.8) ; \\
\text { MYB29-Bol008849 }(1,51.0) ; \\
\text { MYB28-Bol036286 }(1,21.6) ; \\
\text { MYB28-Bol007795 }(1,2.9)\end{array}$ & MYB122-Bol026204 $(3,189.1)$ & \\
\hline Aliphatic Biosynthesis & $\begin{array}{l}\text { ST5b-Bol026202 }(3,5.6) \\
\text { ST5c-Bol030757 }(3,68.6)\end{array}$ & $\begin{array}{c}\text { AOP2-Bo3g052110 }(1,8.4) ; \\
\text { AOP2-Bo9g006240 }(1,11.4) ; \\
\text { FMOGS-OX2-Bol010993 }(1,5.5) \\
\text { GSL-OH-Bol033373 }(1,65.3)\end{array}$ & & \\
\hline Indole Biosynthesis & $\begin{array}{l}\text { ST5a-Bol039395 }(3,25.3) ; \\
\text { ST5a-Bol026200 }(3,82.9)\end{array}$ & $\begin{array}{l}\text { CYP81F1-Bol017375 }(1,2.0) \\
\text { CYP81F1-Bol017376 }(1,7.96)\end{array}$ & $\begin{array}{l}\text { CYP81F4-Bol032712 }(3,21.1) ; \\
\text { CYP81F2-Bol026044 }(3,54.5) ; \\
\text { CYP81F2-Bol014239 }(3,871) ; \\
\text { CYP81F2-Bol012237 }(3,48.3) ; \\
\text { IGMT1-Bol007029 }(3,24.7) ; \\
\text { IGMT2-Bol007030 }(3,171)\end{array}$ & $\begin{array}{l}\text { CYP81F1-Bol028914 }(3,19.6) \\
\text { CYP81F4-Bol032714 }(3,12.3) \\
\text { IGMT1-Bol020663 }(3,652)\end{array}$ \\
\hline
\end{tabular}




\subsection{Upregulation of Transcription Factor-Related Genes and GSL Biosynthesis Genes in the S Line after Inoculation}

We measured the expression levels of 10 GSL biosynthesis genes in the control, mock-treated, and infected plants. In the uninfected control plants, one indole GSL biosynthesis gene, CYP81F1-Bol017376, showed significantly higher expression in the R line compared to the $\mathrm{S}$ line (Figure 4 ). In the S line at 1 DPI, MYB28-Bol036743, MYB29-Bol008849, MYB28-Bol036286, and MYB28-Bol007795, which encode transcription factors genes related to the aliphatic GSLs, showed increased expression (of 5.8-, 51.0-, 21.6-, and 2.9-fold, respectively) in the treated compared to the mock-treated plants (Figure 4, Table 1, Table S2). In addition, the aliphatic GSL biosynthesis genes FMOGS-OX2-Bol010993, AOP2-Bo3g052110, AOP2-Bo9g006240, and GSL-OH-Bol033373 had 5.5-, 8.4-, 11.4-, and 65.3-fold higher expression, respectively (Figure 4, Table 1, Table S3). Among the indole GSL biosynthesis genes, CYP81F1-Bol017375 had 2.0-fold higher expression at 1 DPI and CYP81F1-Bol017376 had 7.96-fold higher expression at 3 DPI in the $S$ line in the treated compared to the mock-treated plants (Figure 4 , Table 1 and Table S4).

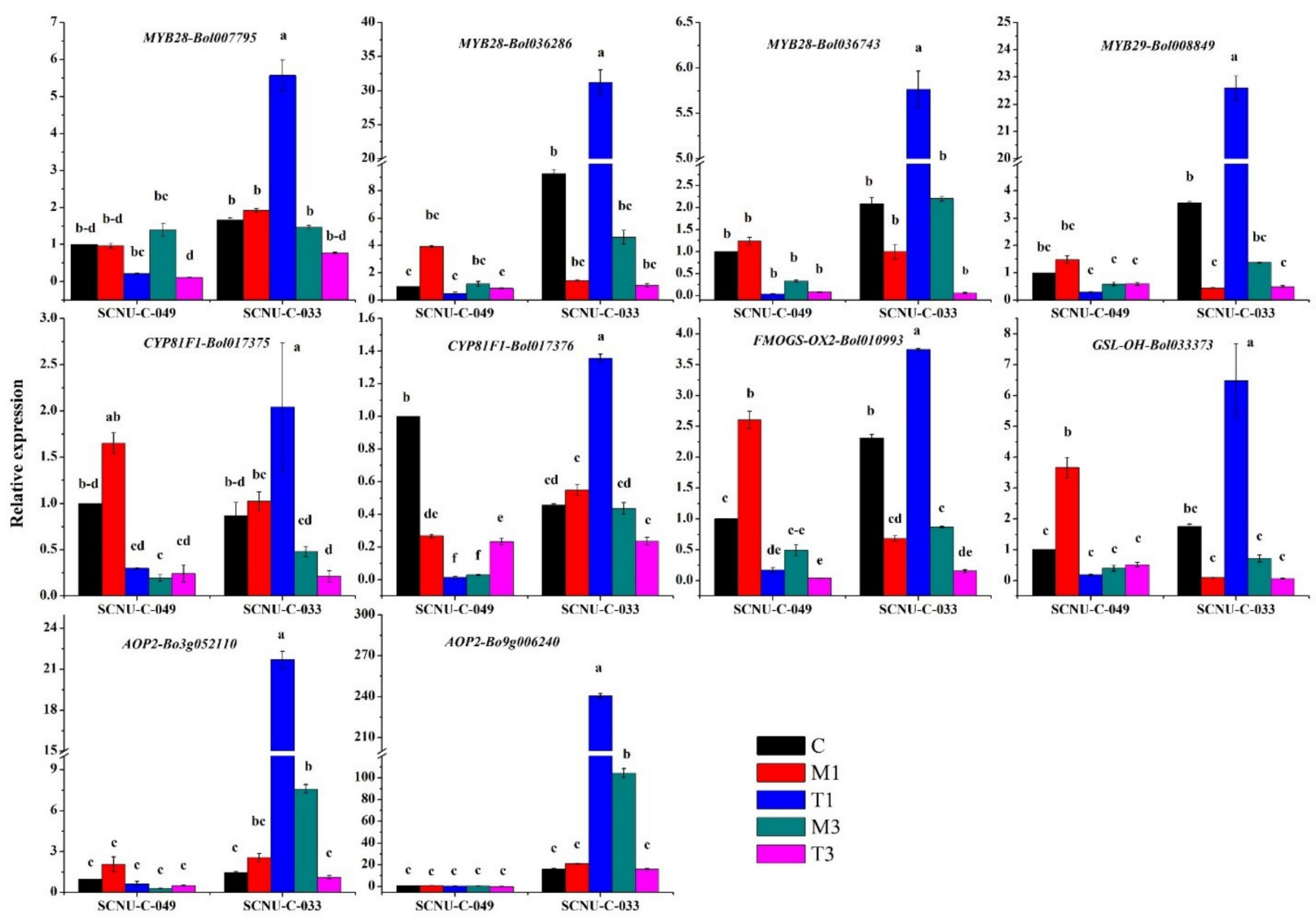

Figure 4. Upregulated transcription-factor- and glucosinolate-biosynthesis-related genes in white-mold-inoculated S (SCNU-C-033) cabbage at 1 DPI compared to mock-treated plants. No similar upregulation was seen in a resistant (R; SCNU-C-049) line. C, control; M1, M3, mock day 1; T1, treated day $1 ; \mathrm{M} 3$, mock day 3; T3, treated day 3 . The means of three biological replicates are presented. Vertical bars indicate standard deviation. Different letters indicate statistically significant differences between $\mathrm{R}$ and $\mathrm{S}$ lines and treatment interactions. R, resistant; $\mathrm{S}$, susceptible.

\subsection{Upregulation of Transcription-Factor-Related Genes and GSL Biosynthesis Genes in Both R and S Lines}

Among the 38 transcription-factor-related genes and GSL biosynthesis genes investigated, the expression of 10 genes was upregulated in both $\mathrm{R}$ and $\mathrm{S}$ lines after inoculation, compared to that in mock-treated plants (Table 1, Figure S2). MYMYB122-Bol026204, which encodes a transcription 
factor related to indole GSLs, had 189-fold increased expression in the R line at 3 DPI (Table 1, Figure S2, and Table S2). Increased expression was also found in infected plants of the R line at 3 DPI for the following indole GSL biosynthesis pathway genes: CYP81F4-Bol032712 by 21.1-fold, CYP81F2-Bol026044 by 54.5-fold, CYP81F2-Bol014239 by 871-fold, CYP81F2-Bol012237 by 48.3-fold, IGMT1-Bol007029 by 24.7-fold, and IGMT2-Bol007030 by 171-fold (Table 1, Figure S2, Table S4). In contrast, the $\mathrm{S}$ line showed much lower upregulation of these genes after infection at 3 DPI compared to that in the mock-treated plants: CYP81F4-Bol032712 expression was increased by 14.5-fold, CYP81F2-Bol026044 by 44.9-fold, CYP81F2-Bol014239 by 1135-fold (1.75-fold lower than in the R-line), CYP81F2-Bol012237 by 12.5-fold, IGMT1-Bol007029 by 10.3-fold, and IGMT2-Bol007030 by 41.1-fold (Table 1, Figure S2, Table S4). Meanwhile, we observed inconsistent responses in the expression of 12 genes (MYB34-Bol007760, MYB34-Bol036262, MYB51-Bol013207, MYB51-Bol030761, ST5b-Bol026201, CYP81F1-Bol028913, CYP81F3-Bol032711, CYP81F3-Bol028919, CYP81F4-Bol028918, FMOGS-OX5-Bol029100, FMOGS-OX5-Bol031350, and AOP2-Bo2g102190) in response to fungal treatments in the $\mathrm{R}$ and $\mathrm{S}$ lines (Figure $\mathrm{S} 3$ ).

2.6. Correlation between the Levels of Individual GSLs and the Expression Level of GSL Biosynthesis Pathway Genes Induced by S. sclerotiorum in the R and S Lines

Heat maps of the fold changes in the expression levels of transcription-factor-related genes and GSL biosynthesis genes that we observed after pathogen inoculation emphasized that these changes were consistent with the changes in the levels of individual GSLs measured in the R and S lines after infection, as compared to the mock-treated controls (Figure 5). We obtained the highest significant positive correlation values for Pearson's correlation coefficient between the levels of the aliphatic GSLs GIB and SIN and the expression of ST5b-Bol026201, between the PRO and GRA levels and AOP2-Bo2g102190 expression, and between the GIV level and ST5b-Bol026202 and ST5c-Bol030757 expression. In contrast, no significant positive correlation was found for GNA and GER (Figure 5A, Supplementary File S4). Among indole GSLs, the GBS level showed significant positive correlation with MYB122-Bol026204, ST5a-Bol026200, ST5a-Bol039395, IGMT1-Bol007029, and IGMT2-Bol007030 expression, the HGBS level with MYB34-Bol036262 and CYP81F3-Bol028919 expression, and the MGBS level with MYB34-Bol036262, MYB122-Bol026204, ST5a-Bol026200, ST5a-Bol039395, and IGMT2-Bol007030 expression, whereas the NGBS level had the highest significant positive correlation with MYB34-Bol007760 expression (Figure 5B, Supplementary File S4).

A)

\begin{tabular}{l}
\multicolumn{1}{c}{ Genes } \\
MYB28-Bol007795 \\
MYB28-Bol036286 \\
MYB28-Bol017019 \\
MYB28-Bol036743 \\
MYB29-Bol008849 \\
ST5b-Bol026202 \\
ST5b-Bol026201 \\
ST5c-Bol030757 \\
FMOGS-OX2-Bol010993 \\
FMOGS-OX5-Bol029100 \\
FMOGS-OX5-Bol031350 \\
GSL-OH-Bol033373 \\
AOP2-Bo2g102190 \\
AOP2-Bo3g052110 \\
AOP2-Bo9g006240
\end{tabular}

B)

\begin{tabular}{|rrrr|r}
\hline GBS & \multicolumn{1}{c}{ HGBS } & \multicolumn{1}{c}{ MGBS } & \multicolumn{1}{l}{ NGBS } \\
\hline-0.230 & 0.184 & 0.089 & -0.095 \\
\hline-0.185 & 0.394 & 0.006 & $\mathbf{0 . 6 7 8}$ \\
\hline 0.363 & $\mathbf{0 . 4 8 9}$ & $\mathbf{0 . 6 0 7}$ & 0.189 \\
\hline $\mathbf{0 . 5 0 3}$ & 0.289 & 0.167 & 0.304 \\
0.227 & 0.011 & 0.307 & -0.034 \\
\hline $\mathbf{0 . 7 0 6}$ & -0.374 & $\mathbf{0 . 5 2 6}$ & -0.134 \\
$\mathbf{0 . 7 3 3}$ & -0.328 & $\mathbf{0 . 5 5 2}$ & -0.077 \\
\hline $\mathbf{0 . 7 5 6}$ & -0.307 & $\mathbf{0 . 5 7 0}$ & -0.077 \\
\hline 0.064 & 0.074 & 0.230 & 0.276 \\
\hline-0.295 & -0.140 & 0.018 & -0.363 \\
\hline 0.121 & 0.259 & -0.376 & 0.065 \\
\hline 0.122 & 0.246 & -0.350 & -0.018 \\
\hline $\mathbf{0 . 5 5 1}$ & -0.388 & $\mathbf{0 . 4 8 8}$ & -0.251 \\
\hline $\mathbf{0 . 4 9 5}$ & -0.368 & 0.411 & -0.238 \\
\hline $\mathbf{0 . 5 4 6}$ & -0.362 & $\mathbf{0 . 4 7 7}$ & -0.221 \\
\hline-0.003 & -0.338 & -0.168 & -0.175 \\
\hline-0.063 & $\mathbf{0 . 5 5 2}$ & -0.277 & 0.339 \\
\hline $\mathbf{0 . 4 8 6}$ & -0.383 & $\mathbf{0 . 4 6 5}$ & -0.282 \\
\hline 0.160 & -0.326 & 0.278 & -0.386 \\
\hline 0.219 & 0.000 & $\mathbf{0 . 4 8 8}$ & 0.069 \\
\hline $\mathbf{0 . 7 3 6}$ & -0.193 & $\mathbf{0 . 5 2 3}$ & -0.076 \\
\hline $\mathbf{0 . 5 5 1}$ & 0.395 & 0.391 & 0.060 \\
\hline $\mathbf{0 . 7 7 7}$ & -0.187 & $\mathbf{0 . 5 7 2}$ & -0.098 \\
\hline & & & \\
\hline
\end{tabular}

Figure 5. Heat maps showing correlation between the levels of aliphatic (A) and indole (B) glucosinolate components and expression of biosynthesis genes under four specific treatments (C, control; M1, mock 
day 1; T1, treated day 1; M3, mock day 3; T3, treated day 3) in white-mold-inoculated R (SCNU-C-049) and S (SCNU-C-033) lines. Blue and bold letters represent statistically significant correlations $(p<0.05)$. For each gene and glucosinolate combination, the values indicate the Pearson correlation coefficient. Red cells represent positive correlation and green cells represent negative correlation. Yellow cells represent no significant correlation. Glucosinolate (GSL) components: GIB, glucoiberin; PRO, progoitrin; GRA, glucoraphanin; SIN, sinigrin; GNA, gluconapin; GIV, glucoiberverin; GER, glucoerucin; GBS, glucobrassicin; NGBS, neoglucobrassicin; MGBS, methoxyglucobrassicin; HGBS, hydroxyglucobrassicin. $R$, resistant; $S$, susceptible.

Principal component analysis (PCA) for the contents of the 11 individual GSL compounds under five different treatment combinations in the R line SCNU-C-049 and the S line SCNU-C-033 of cabbage that we tested revealed an association between white mold resistance and the pattern of GSL accumulation. There were major contrasts among the contents of the individual GSLs. The first four PCs explained $88.3 \%$ of the total variation in the datasets (Table S5). PC1 and PC2 accounted for 43.5\% and $24.2 \%$ of the total variation, respectively, largely corresponding to higher positive coefficients versus lower negative coefficients of individual GSL profiles (Table S5). PC1 clearly distinguished the $\mathrm{R}$ line from the $\mathrm{S}$ line, based on individual GSL profiles (Figure 6 and Table S5) for their positive and negative coefficients respectively. PC2, on the other hand, showed positive association with GIV and GBS in infected samples at 3 DPI (T3) for their positive coefficients, compared to the mock-treated and control samples for their negative coefficients (Figure 6).

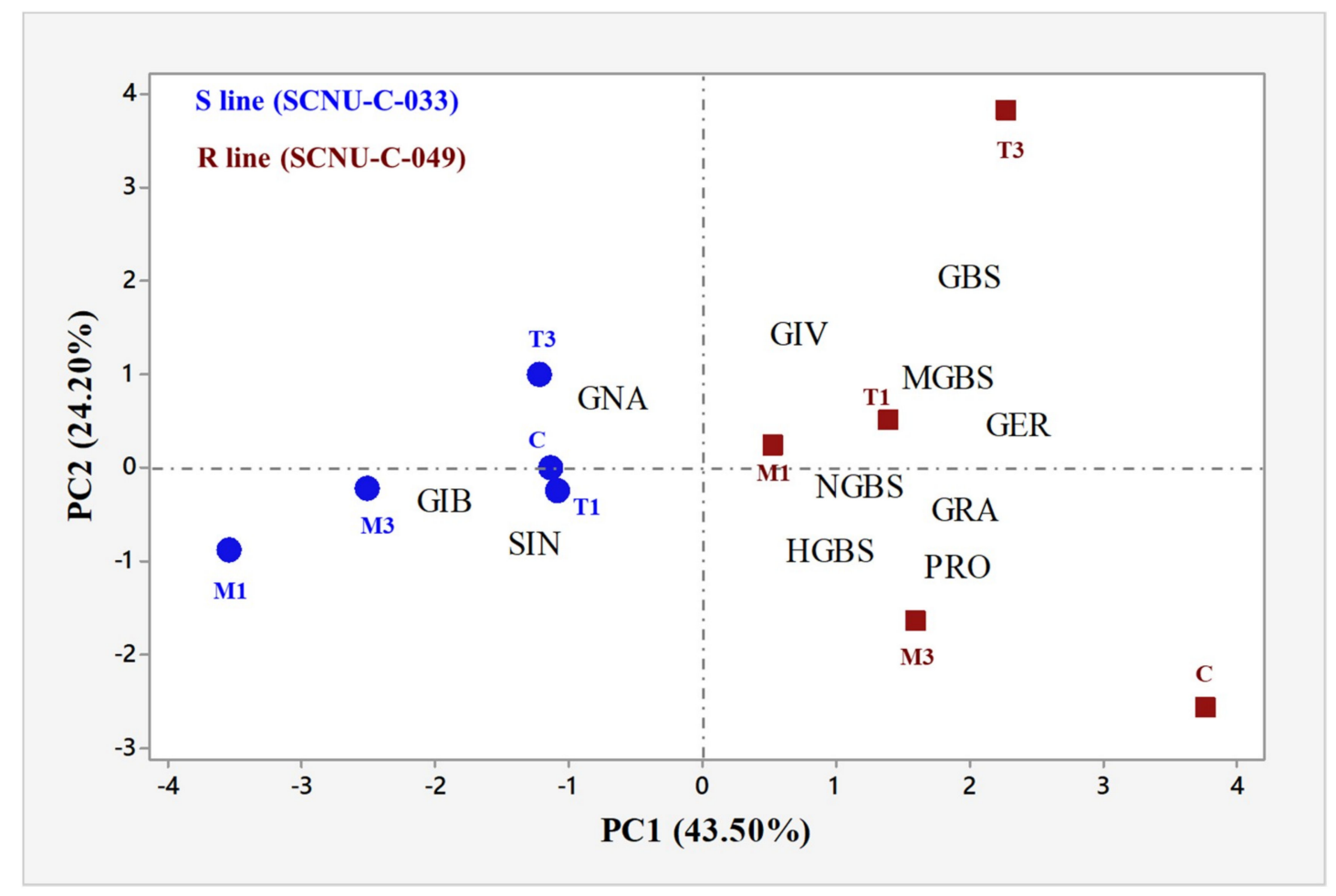

Figure 6. Biplot of white-mold-inoculated R (SCNU-C-049) and S (SCNU-C-033) cabbage lines and individual glucosinolate components, as determined by principal component analysis (PCA). Dark red squares denote mean PC scores of the $\mathrm{R}$ line, and blue circles those of the $\mathrm{S}$ line. Fungal treatments: C, control; M1, mock day 1; T1, treated day 1; M3, mock day 3; T3, treated day 3. Glucosinolate (GSL) components: GIB, glucoiberin; PRO, progoitrin; GRA, glucoraphanin; SIN, sinigrin; GNA, gluconapin, GIV, glucoiberverin; GER, glucoerucin; GBS, glucobrassicin; NGBS, neoglucobrassicin; MGBS, methoxyglucobrassicin; HGBS, hydroxyglucobrassicin. R, resistant; S, susceptible. 


\section{Discussion}

\subsection{Resistance of Cabbage Lines to S. sclerotiorum}

We screened 45 inbred lines of cabbage (B. oleracea var. capitata) and found one completely resistant line, SCNU-C-049 (Figure 1 and Supplementary File S1), whereas a previous report had shown high levels of resistance against $S$. sclerotiorum in wild B. oleracea [10]. The genotypes screened in this study were developed through breeding. Thus, the observed differences explain genotypic variation and indicate that resistance towards S. sclerotiorum is genotype specific. Therefore, the factors controlling the resistance could be transferred to elite cabbage lines.

\subsection{Levels of Total GSLs, GIV, and GBS Were Related to White Mold Resistance}

This study revealed a clear association between plant resistance and GSL accumulation due to pathogen inoculation. In both the R and S lines, the total GSL content, as measured at 3 DPI, did not change significantly after $S$. sclerotiorium inoculation, which indicated that total GSL was not correlated to either resistance or susceptibility in cabbage (Figure S1). These findings were consistent with the results of other studies indicating that pathogen resistance in different Brassica species is not strongly correlated with the overall level of GSLs in each species [45,46]. Notably, we found that the levels of many individual GSLs were altered in the mock-treated plants compared to the control plants. For example, the accumulation of GIB, PRO, GRA, SIN GER, GNA, GBS, HGBS, GBS, and NGBS was generally variable in both control and mock-treated plants of both $\mathrm{R}$ and $\mathrm{S}$ lines (Figure 2). Because of this variability in GSL accumulation in the absence of infection, we compared changes in the contents of the individual GSLs in the samples from the R and S plants after infection to those in mock-treated samples, as a reference. The contents of aliphatic GIV and indole GBS increased in the R line after inoculation (Figure 2), indicating that white mold resistance in cabbage may be accomplished through the accumulation of both aliphatic and indole GSLs. These results were consistent with those of some past studies [36], but not others [53,56,59,60]. In general, however, these data suggest that increased levels of aliphatic GIV and indole GBS may confer resistance to S. sclerotiorum in cabbage.

\subsection{Increased Expression of ST5b-Bol026202 and ST5c-Bol030757 Led to Increased GIV in the R Line}

Secondary alterations of the desulfoglucosinolates GIB and GIV, and other aliphatic GSLs, are linked with the $S T 5 b$ and $S T 5 c$ genes (Figure S4). In this study, increased expression of ST5b-Bol026202 and ST5c-Bol030757 was associated with higher levels of GIV biosynthesis (Figure 5A, Supplementary File S4), confirming results from a previous study [35,38]. Therefore, our data imply that infection-induced upregulation of these genes leads to an increase in the level of GIV, which is linked with white mold resistance (Figures 2 and 3), although molecular studies will be needed to further validate the associations based on these correlations.

\subsection{Increased Levels of Aliphatic GIV and Indole GBS Were Associated with White Mold Resistance}

The pathogen-induced accumulation of GIV seen in the R line, in contrast with the quite static accumulation of GIV in the $S$ line, indicated that GIV has an important role in the resistance conferred by GSL accumulation (Figure 2). In addition, the increased levels of the indole GBS observed in the R as compared to the $S$ line also likely contribute to white mold resistance (Figure 2). These results were consistent with previous observations of higher accumulation of GIV, GBS, and MGBS associated with ringspot resistance in cabbage [38], and increased accumulation of GIV, GBS, and NGBS associated with blackleg resistance in cabbage [37].

\subsection{Expression of MYB28 and MYB34 Likely Induced Expression of GSL Biosynthesis Genes, Leading to Increases in GBS in the R Line}

In Arabidopsis, biotic challenges are believed to be regulated by the upregulation of $M Y B 28$, a novel regulator of aliphatic glucosinolate biosynthesis genes [61]. MYB34 genes directly control 
the biosynthesis of indole GSLs in Arabidopsis [62] and B. oleracea [35,57]. Moreover, in Arabidopsis, MYB34, in conjunction with MYB51 and MYB122, takes part in resistance against Plectosphaerella cucumerina, where the indole-GSL-breakdown-related gene PENETRATION2 (PEN2) plays a major role in triggering the expression of relevant biosynthesis genes upon pathogen inoculation [59]. A MYB34 (Bol007760) gene is also induced in response to mimic biotic elicitation with methyl jasmonate (MeJA) in broccoli (Brassica oleracea var. italica), indicating that this response might follow jasmonic acid (JA) signaling [57]. In our study, the expressions of MYB28-Bol017019 and MYB34-Bol017062 increased by 10.2- and 3.08-fold, respectively, at 1 DPI in R plants inoculated with $S$. sclerotiorum compared to the mock-treated plants (Figure 3). MYB28-Bol017019 and MYB34-Bol017062 may play roles in the transactivation of genes required for the biosynthesis of indole GSLs in response to S. sclerotiorum infection (Figure 2). In our results, the upregulation of MYB28-Bol017019 and MYB34-Bol017062 expression in the R line was associated with the accumulation of aliphatic GIV and indole GBS, respectively, an observation that is also supported by earlier results [35]. In contrast, a number of genes were highly expressed only in the $S$ line after inoculation, indicating that these genes are either not the key regulators, or that any glucosinolate altered by them (for example, gluconapin) has no important role in defense against $S$. sclerotiorum infection (Table 1, Figure 4). From a recent investigation in $B$. oleracea, it is evident that lower accumulation of a GSL compound is not always consistently related to lower expression of one or a few specific GSL biosynthesis genes in all genotypes, and vice versa [35].

\subsection{Accumulation of Indole GBS in the R Line Was Activated by Increased Expression of GSL Biosynthesis Genes}

GBS, which plays a role in antifungal responses in plants, showed increased abundance in the R line, as compared to that in mock-treated plants, in response to $S$. sclerotiorum infection, and this was associated with a significant upregulation of the expression of CYP81F4-Bol032712, CYP81F2-Bol026044, CYP81F2-Bol014239, and CYP81F2-Bol012237 (Figure S2). In a previous study, MeJA treatment increased the expression of CYP81F4 by 2400 -fold in broccoli and 10-fold in cabbage [57], suggesting that resistance against $S$. sclerotiorum is governed by signaling pathways involved in the metabolism of indole GSLs. Experimental evidence has suggested that resistance against necrotrophic pathogens could be modulated by the jasmonic acid/ethylene (JA/ET) signaling pathway [63-66]. Since S. sclerotiorum is a necrotrophic fungus, it is therefore likely that either the JA or ET signaling pathway might be involved in the resistance response of cabbage lines $[67,68]$. Another study also found a similar association between CYP81F2 expression and GBS levels in B. oleracea [69]. The accumulation of GBS and the changes in the expression of CYP81F1-Bol028914, CYP81F2-Bol012237, CYP81F2-Bol014239, CYP81F2-Bol026044, CYP81F4-Bol032712, CYP81F4-Bol032714, IGMT1-Bol007029, IGMT1-Bol020663, and IGMT2-Bol007030 by 0.12-, 2.31-, 1.75-, 2.18-, 1.72-, 0.74-, 5.72-, 2.27-, and 6.30-fold, respectively, in the R as compared to the S line at 3 DPI (Figure S2) indicate that the accumulation of particular GSL components may be associated with physiological responses mediated by gene functions.

The quantities of GSLs in leaf tissues are the result of simultaneous activation of myrosinases (biosynthesis and catabolism), which can upregulate the abundance of GSL components at a specific time period. In vitro studies have reported that MGBS, as well as SIN and GBS [70], has antifungal activity, and that increased accumulation of MGBS confers moderate resistance to Leptosphaeria maculans in cabbage plants [36]. Here, we observed an increase in GBS level in the R line compared to the $S$ line after S. sclerotiorum infection, along with upregulation of CYP81F4-Bol032712, CYP81F2-Bol026044, CYP81F2-Bol014239, and CYP81F2-Bol012237, which encode proteins involved in methoxylation and the conversion of GBS to 4-MGBS (Figure 2). It is likely that both GSL content and GSL biosynthesis pathway genes serve to confer resistance to $S$. sclerotiorum. Our findings also agree with the report that in Arabidopsis, upon infection with Blumeria graminis Erysiphe pisi and Plectosphaerella cucumerina, CYP81F2 expression induces antifungal defenses [55]. 
3.7. Accumulation of Aliphatic GIV with Expression of ST5b-Bol026202 and ST5c-Bol030757 and Indole GBS with ST5a-Bol026200 and ST5a-Bol039395 May Play a Role in Resistance

A notably consistent association between GSL content and expression levels of genes was observed in our heat map (Figure 5). The Pearson's correlation coefficient showed the highest significant positive correlations between the levels of the aliphatic GIV and the expressions of ST5b-Bol026202 and ST5c-Bol030757, and between the levels of the indolic GBS and the expressions of ST5a-Bol026200 and ST5a-Bol039395 (Figures 2, 3 and 5). These data show that changes in the expression levels of these genes correlate to the contents of individual GSLs in response to $S$. sclerotiorum infection. The PCA showed a strong association between the accumulation of GIV and GBS in the R line at 3 DPI for their positive coefficients at PC1 and PC2 (Figure 6). These GSLs might function in the regulation of resistance to white mold in cabbage. These results were also supported by a previous observation that the contents of aliphatic and indole GSLs were correlated with complete resistance to blackleg in cabbage [36]. Lastly, the upregulation of GSL biosynthesis genes occurred within 1 to 3 days after inoculation, at the time of the first appearance of disease symptoms. GSLs began to accumulate at 3 DPI. This suggests that at the time when symptoms first appeared, GSL biosynthesis genes were induced in order to initiate a GSL-mediated resistance response.

\subsection{Association of GSL Biosynthesis Genes and Accumulation of Individual GSLs in the S Line}

Ten GSL biosynthesis genes were highly expressed in the S line at 1 DPI (Figure 4). The PCA analysis showed positive association among individual GSLs and the $S$ line (i.e., GIB, SIN, and GNA) in regard to their negative coefficients across PC1 (Figure 6). Among these individual GSLs, only one aliphatic GSL, GNA, accumulated significantly in the S line (Figure 2). Therefore, GNA may confer susceptibility to $S$. sclerotiorum in cabbage, which is consistent with results from another study indicating that GNA exhibits increased accumulation in clubroot-susceptible B. napus plants and is likely a key factor in the pathogenesis of clubroot disease [71].

\section{Materials and Methods}

\subsection{Plant Materials and Growth Conditions}

Seeds of 45 cabbage (B. oleracea var. capitata) inbred lines (Supplementary File S1) were germinated in multi-pot trays using coco-peat soil in a growth chamber at $24{ }^{\circ} \mathrm{C}$ and $60 \%$ relative humidity (RH), with a $16 \mathrm{~h} / 8 \mathrm{~h}$ (light/dark) photoperiod. When the seedlings bore two visible leaves $(10 \times 10 \times 12 \mathrm{~cm})$, they were transplanted to large pots, one plant per pot, filled with a mixture of $50 \%$ coco-peat and $50 \%$ soil. Plants were inoculated at the ninth-leaf stage (third leaf, stem) and were kept in an inoculation chamber $\left(24{ }^{\circ} \mathrm{C}, 98 \% \mathrm{RH}\right)$ covered with black polyvinyl to maintain high $\mathrm{RH}$, as it positively influences disease progression [72]. They were evaluated for white mold disease one month after head formation.

\subsection{Inoculum Preparation}

An isolate (Muan) of S. sclerotiorum, obtained originally from field-sown cabbage plants in Muan, South Korea, was maintained and cultured on potato dextrose agar (PDA; 25\% potato, $2.5 \%$ dextrose and $1.5 \%$ agar, $\mathrm{pH} 5.8$ ). The isolate was maintained at $4{ }^{\circ} \mathrm{C}$ in darkness, and cultured twice before inoculation at $23^{\circ} \mathrm{C}$ in darkness. Mycelial agar plugs ( $7 \mathrm{~mm}$ in diameter) punched from the margin of a 3-day-old culture of $S$. sclerotiorum grown on PDA were used as the inoculum [73,74].

\subsection{Inoculation Technique and Disease Assessment}

We reared 15 seedlings against each genotype to obtain seedlings of homogenized growth at the day of inoculation. We used those plants that reached ninth leaf at the day of inoculation. Three different plants from each of the 45 inbred lines (biological replicates) were inoculated in the third-youngest leaf of ninth-leaf-stage plants. Control plants remained undisturbed, whereas mock-treatment was done with mycelium-free agar plugs. Two inoculation procedures described in 
Zhao and Meng [74,75] and Yu et al. [67] were used, with modifications (Table S6), to assess resistance to $S$. sclerotiorum. The first procedure was inoculation of the third leaf of ninth-leaf-stage plants with mycelial agar plugs in a growth chamber, to evaluate leaf resistance. The mycelial agar plug was inoculated on the middle of each leaf. The inoculated leaves were sprayed with a fine mist of water and covered with black polyvinyl to maintain a high level of relative humidity, and the plants were kept at $24{ }^{\circ} \mathrm{C}$ in darkness. The lesion was measured from 1 to 5 days post inoculation (DPI) in all lines, and was standardized with presence and absence of disease symptoms. The second procedure was stem inoculation with mycelial agar plugs that was conducted in a different set of plants, to measure stem resistance at the same stage. Stems of each inbred line in each replicate were inoculated with mycelial agar plugs at a height of $20 \mathrm{~cm}$ above the ground. Each plug was affixed with alpin and plastic wrap to ensure close contact of the inocula with the stem surface, and to maintain humidity. The plants were sprayed with water mist every day after inoculation for 3 days. The stem lesions were measured at 7 DPI. In addition to using these two procedures, we also inoculated cabbage heads (one month after head formation) and then observed the head lesions at 10 DPI (with the head right side up) and at 15 DPI (with the head upside down). Leaf disease progression was examined in the selected $\mathrm{R}$ line (SCNU-C-049) and S line (SCNU-C-033) up to 5 days post inoculation (DPI) to make a decision on the sampling sites for RNA extraction and HPLC analysis (Figure 7).

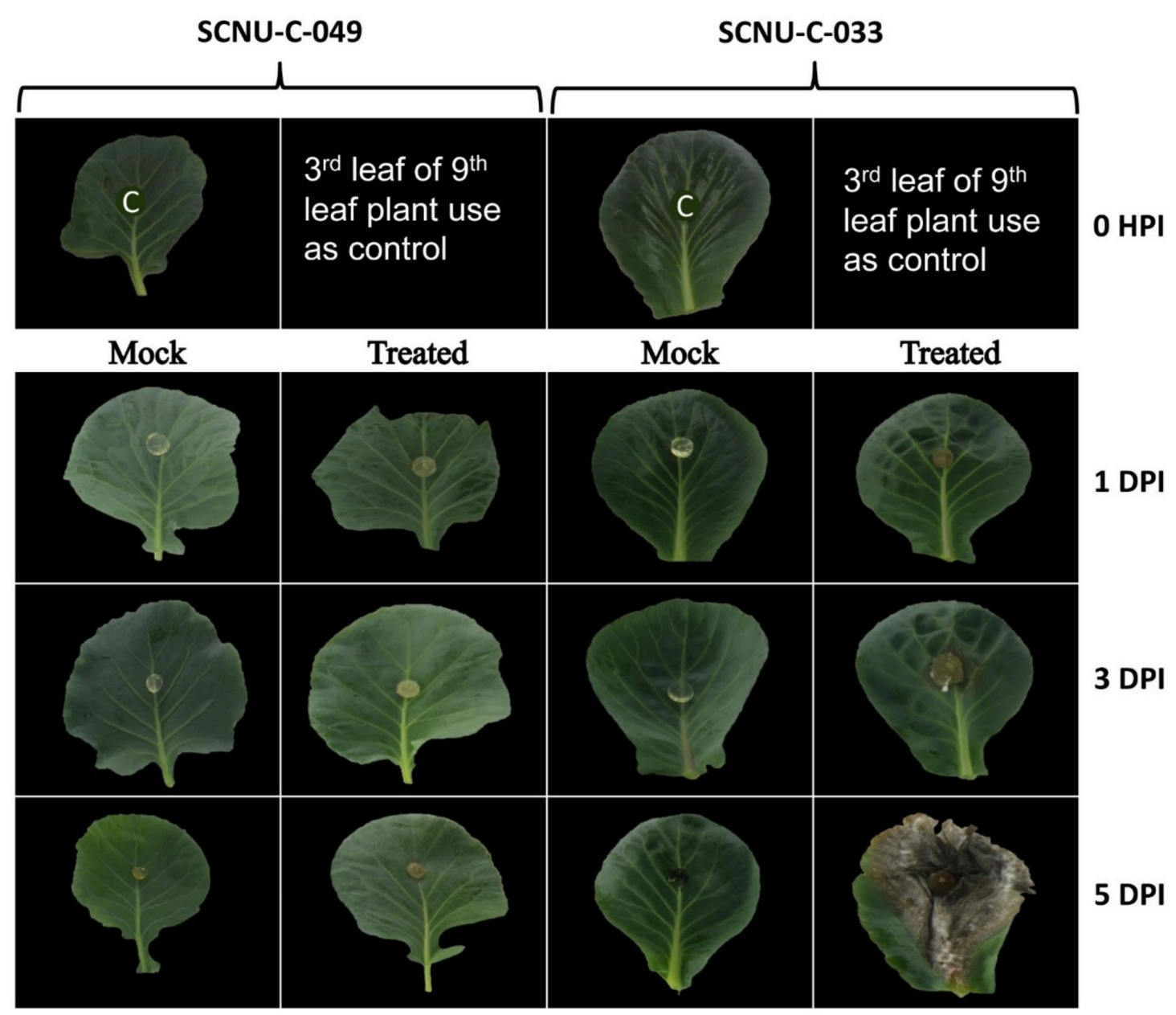

Figure 7. White mold disease progress in resistant (R; SCNU-C-049) and sensitive (S; SCNU-C-033) lines of cabbage. The third-youngest leaf was infected at the of ninth leaf stage of each plant. Infected leaves were examined at 0 hours post inoculation (HPI), and then from 1 to 5 days post inoculation (DPI). C, control plant leaf (no inoculation). 'Mock' treatment(s) - were those done with mycelium-free agar plugs. 


\subsection{Leaf Sampling and Preparation for HPLC and Gene Expression Analysis}

Leaf samples at 1 and 3 DPI were simultaneously sampled from the $\mathrm{R}$ line and the $\mathrm{S}$ line from each of the control, mock-treated, and S. sclerotiorum-infected plants, both to evaluate the levels of endogenous GSLs and to quantify the expression of GSL biosynthetic pathway genes (Figure S4). Inoculated but non-infected and mock-treated leaf pieces were collected at sampling. The collected samples were flash-frozen in liquid nitrogen and immediately stored in a $-80{ }^{\circ} \mathrm{C}$ freezer until needed for reverse transcription quantitative PCR (RT-qPCR) and HPLC analyses.

\subsection{GSL Content Measurements}

Desulfoglucosinolates were extracted from leaf samples from three biological replicates for each of the control, mock-treated, and S. sclerotiorum-infected plants, via a modified HPLC protocol as previously described $[35,57,76]$. The leaf samples stored at $-80{ }^{\circ} \mathrm{C}$ were ground to a very fine powder after methanol treatment. The ground-up leaf tissues were kept at $70{ }^{\circ} \mathrm{C}$ for $10 \mathrm{~min}$, then at room temperature for about an hour, and then centrifuged for $8 \mathrm{~min}$ at $10,000 \times g$ at $4{ }^{\circ} \mathrm{C}$ to remove undesirable sediment. The supernatant was subjected to anion-exchange chromatography, and the resulting effluent was considered the crude GSL sample. This crude GSL sample was then desulfurized as previously described $[35,57,76]$, and then passed through an elution process with $1 \mathrm{ml}$ of distilled water. The samples were subjected to high-speed centrifugation at $20,000 \times g$ for $4 \mathrm{~min}$ at $4{ }^{\circ} \mathrm{C}$, and then filtered using a polytetrafluoroethylene filter $(13 \mathrm{~mm}, 0.2 \mu \mathrm{m}$; Advantec, Pleasanton, CA, USA). Purified GSLs were analyzed by HPLC on a Waters 2695 HPLC system (Waters, Milford, MA, USA) equipped with a C18 column (Zorbax Eclipse XBD C18, $4.6 \mathrm{~mm} \times 150 \mathrm{~mm}$; Agilent Technologies, Palo Alto, CA, USA). Water and acetonitrile were used as the mobile-phase solvents. The content of individual glucosinolates was measured at a wavelength of $229 \mathrm{~nm}$ using a PDA996 UV-visible detector (Waters). A standard curve was used for the quantification of the identified GSLs, with sinigrin (SIN) as a standard. HPLC-MS analysis (Agilent 1200 series, Agilent Technologies) was used for the identification of individual GSLs [57].

\subsection{Primer Design for Expression Analysis of GSL Biosynthesis Genes}

We selected 38 genes encoding proteins involved in GSL biosynthesis pathways, of which 11 are transcription factors: five related to the aliphatic and six to the indole biosynthesis pathways. Of the remaining 27 genes, 10 encode proteins involved in aliphatic GSL biosynthesis, and 17 proteins involved in indole GSL biosynthesis (Table S7, Figure S4) [35,57]. The primers were previously designed, and their efficiencies were calculated following Robin et al. [35]. In order to test the efficiency of primers, pooled cDNA of cabbage inbred lines of the same concentration of $300 \mathrm{ng} \cdot \mu \mathrm{L}^{-1} \mathrm{was}$ serially diluted 10 times per dilution. One $\mu \mathrm{L}$ samples of diluted cDNA at $10^{0}, 10^{-1}, 10^{-2}, 10^{-3}$, $10^{-4}$ and $10^{-5}$ concentrations of original were used as templates in each reaction, with forward and reverse primers. The qRT-PCR reaction was conducted for 40 cycles with melting curves in triplicate without template control. Semi-log plots of $\mathrm{Ct}$ versus fold dilutions were drawn to determine the slope. Primer efficiencies were calculated using the following equation: $e=10^{\wedge(-1 / \text { slope })}$. A value of slope of -3.321928 indicated $100 \%$ efficiency of a primer. Primers with efficiency levels of $90 \%$ to $100 \%$ were selected for expression analysis. Primers were often redesigned to obtain efficiency within the expected range.

\section{7. cDNA Synthesis and RT-qPCR Analysis}

Total RNA was extracted from frozen, cold-treated leaf samples of cabbage with an RNeasy Mini kit (Qiagen, Hilden, Germany), following the manufacturer's guidelines. DNA was removed from the samples using RNase-free DNase (Promega, Madison, WI, USA), also according to the manufacturer's instructions. Purity of the extracted RNA was determined by the 260/280 nm ratio as quantified with a Nanodrop ${ }^{\circledR}$ ND-1000 and NanoDrop v3.7 software (Thermo Fisher Scientific, Waltham, MA, 
USA) (Supplementary File S5). The integrity of RNA was checked by agarose gel electrophoresis [77]. Complementary DNA (cDNA) was synthesized by using $5 \mu \mathrm{g}$ of extracted RNA and an oligo (dT) primer of first strand cDNA synthesis kit (Invitrogen, Madison, WI, USA) following the manufacturer's instructions, and the equality of cDNA for the samples was normalized by comparing the thickness of the PCR amplicons from the B. oleracea actin 1 gene [58]. RT-PCR was conducted using $1 \mu \mathrm{L}$ of cDNA, $1 \mu \mathrm{L}$ of forward and reverse primers (10 pmol concentration), $8 \mu \mathrm{L}$ of Prime Taq Premix $(2 \times)$ containing $1 \mathrm{U}$ Taq polymerase (GENETBIO Inc., Korea), and $9 \mu \mathrm{L}$ of double distilled water, with a total volume of $20 \mu \mathrm{L}$. PCR conditions: 5 min initial denaturation followed by denaturation at $94{ }^{\circ} \mathrm{C}$ and 25 cycles of denaturation at $94{ }^{\circ} \mathrm{C}$ for $30 \mathrm{~s}$, annealing at $56^{\circ} \mathrm{C}$ for $30 \mathrm{~s}$, extension at $72{ }^{\circ} \mathrm{C}$ for $45 \mathrm{~s}$, and final extension at $72{ }^{\circ} \mathrm{C}$ for $7 \mathrm{~min}$. PCR products were run on a $1.5 \%$ agarose gel along with a $100 \mathrm{bp}$ size DNA ladder, stained with HiQ blue mango $(20,000 \times)$, and pictured under UV light to obtain expected amplicons. A quantitative PCR (qPCR) was performed using iTaqTM SYBRR Green Super-mix with ROX dye (Bio-Rad, Hercules, CA, USA) to investigate the expression levels of GSL biosynthesis genes. Each reaction was carried out in a $20 \mu \mathrm{L}$ total volume containing $1 \mu \mathrm{L}$ cDNA template $\left(60 \mathrm{ng}_{\mu \mathrm{L}}^{-1}\right.$ concentration), $1 \mu \mathrm{L}$ forward and $1 \mu \mathrm{L}$ reverse primers (both of $10 \mathrm{pmol}$ concentration), $10 \mu \mathrm{L}$ iTaqTM SYBRR Green Super-mix (Bio-Rad, Hercules, CA, USA), and $7 \mu \mathrm{L}$ ultra-pure water. The qPCR was run to conduct denaturation, annealing, and amplification, with the following set conditions: $95^{\circ} \mathrm{C}$ for $10 \mathrm{~min}$ followed by 40 cycles of $95^{\circ} \mathrm{C}$ for $20 \mathrm{~s}, 58^{\circ} \mathrm{C}$ for $20 \mathrm{~s}$, and $72{ }^{\circ} \mathrm{C}$ for $30 \mathrm{~s}$. Signal acquisition was performed for each sample, and the fluorescence intensity was recorded at the end of each cycle. Individual biological samples were read three times as technical replicates. The quantification cycle (Cq) analysis was conducted using Light Cycler 96 software (Roche, Mannheim, Germany), and a popular method, the Livak's comparative $2^{-\triangle \Delta C t}$ method [78], was used for calculating the relative expression of each gene.

\subsection{Statistical Analysis}

One-way analysis of variance (ANOVA) was performed to test the statistical significance of the differences in the results of the different treatments between the R line, SCNU-C-049, and the S line, SCNU-C-033, using Minitab 18 statistical software (Minitab Inc., State College, PA, USA). A heat map was drawn in Microsoft Excel to show the correlation between GSL content and GSL biosynthetic gene expression according to each specific treatment of the $\mathrm{R}$ and $\mathrm{S}$ lines, using conditional formatting options (Tables S1-S4). To explore statistical significances of the differences among the treatments, a one-way ANOVA was conducted, followed by Tukey's pairwise comparison as a post hoc test. Relevant statistical measures, including ANOVA, for individual GSL contents and expression level of genes are presented in Tables S8 and S9. A principal component analysis with correlation matrix command was conducted using Minitab 18 (State College, PA, USA) statistical software to explore association between glucosinolate contents after S. sclerotiorum inoculation and resistance of cabbage lines.

\section{Conclusions}

The GSL profiling and expression analysis of GSL-related genes in cabbage infected by S. sclerotiorum identified a direct association between the expression of the genes and the abundances of the corresponding GSLs in a resistant and a susceptible line of cabbage. This study showed that the simultaneous accumulation of pathogen-induced aliphatic GIV and indole GBS were associated with white mold resistance in cabbage. Noteworthy differences in expression at 3 days post inoculation were observed for two genes encoding aliphatic biosynthetic proteins, ST5b-Bol026202 and ST5c-Bol030757, and two genes encoding indole biosynthesis genes, ST5a-Bol026200 and ST5a-Bol039395. The GSLs and the corresponding genes identified in this study are candidate genetic and biochemical determinants of resistance, and could be tested in efforts to improve white mold resistance in cabbage.

Supplementary Materials: Supplementary materials can be found at http:/ / www.mdpi.com/1422-0067/19/12/ 4037/s1. References [79,80] are cited in Supplementary Figure S4. 
Author Contributions: M.A. inoculated and managed the experimental plants, collected samples, prepared cDNA, performed qPCR analysis, and prepared the manuscript draft. A.H.K.R. performed the statistical analysis and critically edited the manuscript. J.-H.L., and H.-J.J., assisted cDNA preparation and qPCR analysis. H.-T.K. conducted HPLC analysis. J.-I.P., A.H.K.R., and I.-S.N. formulated and designed the research.

Funding: We thank the cabbage germplasm project, Sunchon National University, Republic of Korea for providing seeds. This study was supported by the Center for Horticultural Seed Development (Golden Seed Project no.213007-05-3-CG100) of the Ministry of Agriculture, Food and Rural Affairs in the Republic of Korea (MAFRA).

Conflicts of Interest: There is no conflict of interest among the authors for publishing the manuscript.

\section{References}

1. Boland, G.; Hall, R. Index of plant hosts of Sclerotinia sclerotiorum. Can. J. Plant Pathol. 1994, 16, 93-108. [CrossRef]

2. Purdy, L.H. Sclerotinia sclerotiorum: History, diseases and symptomatology, host range, geographic distribution, and impact. Phytopathology 1979, 69, 875-880. [CrossRef]

3. Jamaux, I.; Gelie, B.; Lamarque, C. Early stages of infection of rapeseed petals and leaves by Sclerotinia sclerotiorum revealed by scanning electron microscopy. Plant Pathol. 1995, 44, 22-30. [CrossRef]

4. Del Río, L.; Bradley, C.; Henson, R.; Endres, G.; Hanson, B.; McKay, K.; Halvorson, M.; Porter, P.; Le Gare, D.; Lamey, H. Impact of sclerotinia stem rot on yield of canola. Plant Dis. 2007, 91, 191-194. [CrossRef]

5. Zhao, J.; Peltier, A.; Meng, J.; Osborn, T.; Grau, C. Evaluation of sclerotinia stem rot resistance in oilseed Brassica napus using a petiole inoculation technique under greenhouse conditions. Plant Dis. 2004, 88, 1033-1039. [CrossRef]

6. Wu, J.; Cai, G.; Tu, J.; Li, L.; Liu, S.; Luo, X.; Zhou, L.; Fan, C.; Zhou, Y. Identification of qtls for resistance to sclerotinia stem rot and bnac. Igmt5. A as a candidate gene of the major resistant QTL SRC6 in Brassica napus. PLoS ONE 2013, 8, e67740.

7. Garg, H.; Atri, C.; Sandhu, P.S.; Kaur, B.; Renton, M.; Banga, S.K.; Singh, H.; Singh, C.; Barbetti, M.J.; Banga, S.S. High level of resistance to Sclerotinia sclerotiorum in introgression lines derived from hybridization between wild crucifers and the crop Brassica species B. napus and B. juncea. Field Crops Res. 2010, 117, 51-58. [CrossRef]

8. Lefol, C.; Seguin-Swartz, G.; Morrall, R. Resistance to Sclerotinia sclerotiorum in a weed related to canola. Can. J. Plant Pathol. 1997, 19, 113.

9. Chen, H.-F.; Wang, H.; Li, Z.-Y. Production and genetic analysis of partial hybrids in intertribal crosses between Brassica species (B. rapa, B. napus) and capsella bursa-pastoris. Plant Cell Rep. 2007, 26, 1791-1800. [CrossRef]

10. Mei, J.; Qian, L.; Disi, J.; Yang, X.; Li, Q.; Li, J.; Frauen, M.; Cai, D.; Qian, W. Identification of resistant sources against Sclerotinia sclerotiorum in Brassica species with emphasis on B. oleracea. Euphytica 2011, 177, 393-399. [CrossRef]

11. Bennett, R.N.; Wallsgrove, R.M. Secondary metabolites in plant defense mechanisms. New Phytol. 1994, 127, 617-633. [CrossRef]

12. Kliebenstein, D. Secondary metabolites and plant/environment interactions: A view through Arabidopsis thaliana tinged glasses. Plant Cell Environ. 2004, 27, 675-684. [CrossRef]

13. Lattanzio, V.; Lattanzio, V.M.; Cardinali, A. Role of phenolics in the resistance mechanisms of plants against fungal pathogens and insects. Phytochem. Adv. Res. 2006, 661, $23-67$.

14. Wink, M. Plant breeding: Importance of plant secondary metabolites for protection against pathogens and herbivores. Theor. Appl. Genet. 1988, 75, 225-233. [CrossRef]

15. Fahey, J.W.; Zalcmann, A.T.; Talalay, P. The chemical diversity and distribution of glucosinolates and isothiocyanates among plants. Phytochemistry 2001, 56, 5-51. [CrossRef]

16. Mithen, R. Glucosinolates-biochemistry, genetics and biological activity. Plant Growth Regul. 2001, 34, 91-103. [CrossRef]

17. Bekaert, M.; Edger, P.P.; Hudson, C.M.; Pires, J.C.; Conant, G.C. Metabolic and evolutionary costs of herbivory defense: Systems biology of glucosinolate synthesis. New Phytol. 2012, 196, 596-605. [CrossRef]

18. Aires, A.; Mota, V.; Saavedra, M.; Rosa, E.; Bennett, R. The antimicrobial effects of glucosinolates and their respective enzymatic hydrolysis products on bacteria isolated from the human intestinal tract. J. Appl. Microbiol. 2009, 106, 2086-2095. [CrossRef] 
19. Giamoustaris, A.; Mithen, R. The effect of modifying the glucosinolate content of leaves of oilseed rape (Brassica napus ssp. oleifera) on its interaction with specialist and generalist pests. Ann. Appl. Biol. 1995, 126, 347-363.

20. Manici, L.M.; Lazzeri, L.; Palmieri, S. In vitro fungitoxic activity of some glucosinolates and their enzyme-derived products toward plant pathogenic fungi. J. Agric. Food Chem. 1997, 45, 2768-2773. [CrossRef]

21. Agerbirk, N.; Olsen, C.E.; Sorensen, H. Initial and final products, nitriles, and ascorbigens produced in myrosinase-catalyzed hydrolysis of indole glucosinolates. J. Agric. Food Chem. 1998, 46, 1563-1571. [CrossRef]

22. Brader, G.; Tas, E.; Palva, E.T. Jasmonate-dependent induction of indole glucosinolates in Arabidopsis by culture filtrates of the nonspecific pathogen Erwinia carotovora. Plant Physiol. 2001, 126, 849-860. [CrossRef] [PubMed]

23. Tierens, K.F.-J.; Thomma, B.P.; Brouwer, M.; Schmidt, J.; Kistner, K.; Porzel, A.; Mauch-Mani, B.; Cammue, B.P.; Broekaert, W.F. Study of the role of antimicrobial glucosinolate-derived isothiocyanates in resistance of Arabidopsis to microbial pathogens. Plant Physiol. 2001, 125, 1688-1699. [CrossRef] [PubMed]

24. Barth, C.; Jander, G. Arabidopsis myrosinases TGG1 and TGG2 have redundant function in glucosinolate breakdown and insect defense. Plant J. 2006, 46, 549-562. [CrossRef] [PubMed]

25. Stotz, H.U.; Sawada, Y.; Shimada, Y.; Hirai, M.Y.; Sasaki, E.; Krischke, M.; Brown, P.D.; Saito, K.; Kamiya, Y. Role of camalexin, indole glucosinolates, and side chain modification of glucosinolate-derived isothiocyanates in defense of Arabidopsis against Sclerotinia sclerotiorum. Plant J. 2011, 67, 81-93. [CrossRef] [PubMed]

26. Calmes, B.; N’Guyen, G.; Dumur, J.; Brisach, C.A.; Campion, C.; Iacomi, B.; Pigné, S.; Dias, E.; Macherel, D.; Guillemette, T. Glucosinolate-derived isothiocyanates impact mitochondrial function in fungal cells and elicit an oxidative stress response necessary for growth recovery. Front. Plant Sci. 2015, 6, 414. [CrossRef] [PubMed]

27. Hogge, L.; Reed, D.; Underhill, E.; Haughn, G. Hplc separation of glucosinolates from leaves and seeds of Arabidopsis thaliana and their identification using thermospray liquid chramatography/mass spectrometry. J. Chromatogr. Sci. 1988, 26, 551-556. [CrossRef]

28. Mithen, R.; Raybould, A.; Giamoustaris, A. Divergent selection for secondary metabolites between wild populations of Brassica oleracea and its implications for plant-herbivore interactions. Heredity 1995, 75, 472. [CrossRef]

29. Benderoth, M.; Textor, S.; Windsor, A.J.; Mitchell-Olds, T.; Gershenzon, J.; Kroymann, J. Positive selection driving diversification in plant secondary metabolism. Proc. Natl. Acad. Sci. USA 2006, 103, 9118-9123. [CrossRef]

30. Hopkins, R.J.; van Dam, N.M.; van Loon, J.J. Role of glucosinolates in insect-plant relationships and multitrophic interactions. Annu. Rev. Entomol. 2009, 54, 57-83. [CrossRef]

31. Schnug, E.; Haneklaus, S.; Murphy, D. Impact of sulphur fertilization on fertilizer nitrogen efficiency. Sulphur Agricult. 1993, 17, 12.

32. Krumbein, A.; Schonhof, I.; Rühlmann, J.; Widell, S. Influence of sulphur and nitrogen supply on flavour and health-affecting compounds in Brassicaceae. In Plant Nutrition; Springer: Dordrecht, The Netherlands, 2001; pp. 294-295.

33. Salac, I.; Haneklaus, S.; Bloem, E.; Booth, E.; Sutherland, K.; Walker, K.; Schnug, E. Influence of sulfur fertilization on sulfur metabolites, disease incidence and severity of fungal pathogens in oilseed rape in Scotland. Landbauforschung Vôlkenrode 2006, 56, 1-4.

34. Schonhof, I.; Blankenburg, D.; Müller, S.; Krumbein, A. Sulfur and nitrogen supply influence growth, product appearance, and glucosinolate concentration of broccoli. J. Plant Nutr. Soil Sci. 2007, 170, 65-72. [CrossRef]

35. Robin, A.H.K.; Yi, G.-E.; Laila, R.; Yang, K.; Park, J.-I.; Kim, H.R.; Nou, I.-S. Expression profiling of glucosinolate biosynthetic genes in Brassica oleracea L. var. capitata inbred lines reveals their association with glucosinolate content. Molecules 2016, 21, 787.

36. Robin, A.H.K.; Yi, G.-E.; Laila, R.; Hossain, M.R.; Park, J.-I.; Kim, H.R.; Nou, I.-S. Leptosphaeria maculans alters glucosinolate profiles in blackleg disease-resistant and-susceptible cabbage lines. Front. Plant Sci. 2017, 8, 1769. [CrossRef] [PubMed]

37. Robin, A.H.K.; Hossain, M.R.; Park, J.-I.; Kim, H.R.; Nou, I.-S. Glucosinolate profiles in cabbage genotypes influence the preferential feeding of diamondback moth (plutella xylostella). Front. Plant Sci. 2017, 8, 1244. [CrossRef] [PubMed] 
38. Abuyusuf, M.; Robin, A.; Kim, H.-T.; Islam, M.; Park, J.-I.; Nou, I.-S. Altered glucosinolate profiles and expression of glucosinolate biosynthesis genes in ringspot-resistant and susceptible cabbage lines. Int. J. Mol. Sci. 2018, 19, 2833. [CrossRef] [PubMed]

39. Rask, L.; Andréasson, E.; Ekbom, B.; Eriksson, S.; Pontoppidan, B.; Meijer, J. Myrosinase: Gene family evolution and herbivore defense in Brassicaceae. Plant Mol. Biol. 2000, 42, 93-114. [CrossRef]

40. Wittstock, U.; Halkier, B.A. Glucosinolate research in the Arabidopsis era. Trends Plant Sci. 2002, 7, $263-270$. [CrossRef]

41. Agrawal, A.A.; Kurashige, N.S. A role for isothiocyanates in plant resistance against the specialist herbivore pieris rapae. J. Chem. Ecol. 2003, 29, 1403-1415. [CrossRef]

42. Mewis, I.; Appel, H.M.; Hom, A.; Raina, R.; Schultz, J.C. Major signaling pathways modulate arabidopsis glucosinolate accumulation and response to both phloem-feeding and chewing insects. Plant Physiol. 2005, 138, 1149-1162. [CrossRef] [PubMed]

43. Kliebenstein, D.; Pedersen, D.; Barker, B.; Mitchell-Olds, T. Comparative analysis of quantitative trait loci controlling glucosinolates, myrosinase and insect resistance in Arabidopsis thaliana. Genetics 2002, 161, 325-332. [PubMed]

44. Mikkelsen, M.D.; Petersen, B.L.; Glawischnig, E.; Jensen, A.B.; Andreasson, E.; Halkier, B.A. Modulation of CYP79 genes and glucosinolate profiles in arabidopsis by defense signaling pathways. Plant Physiol. 2003, 131, 298-308. [CrossRef] [PubMed]

45. Mithen, R.F.; Magrath, R. Glucosinolates and resistance to Leptosphaeria maculans in wild and cultivated Brassica species. Plant Breeding 1992, 108, 60-68. [CrossRef]

46. Sexton, A.C.; Kirkegaard, J.A.; Howlett, B.J. Glucosinolates in Brassica juncea and resistance to australian isolates of Leptosphaeria maculans, the blackleg fungus. Australasian Plant Pathol. 1999, 28, 95-102. [CrossRef]

47. Li, Y.; Kiddle, G.; Bennett, R.; Wallsgrove, R. Local and systemic changes in glucosinolates in chinese and european cultivars of oilseed rape (Brassica napus L.) after inoculation with Sclerotinia sclerotiorum (stem rot). Ann. Appl. Biol. 1999, 134, 45-58. [CrossRef]

48. Sotelo, T.; Lema, M.; Soengas, P.; Cartea, M.; Velasco, P. In vitro activity of glucosinolates and their degradation products against Brassica pathogenic bacteria and fungi. Appl. Environ. Microbiol. 2014, AEM, 03142-03144.

49. Giamoustaris, A.; Mithen, R. Glucosinolates and disease resistance in oilseed rape (Brassica napus ssp. oleifera). Plant Pathol. 1997, 46, 271-275. [CrossRef]

50. Doughty, K.J.; Porter, A.J.R.; Morton, A.M.; Kiddle, G.; Bock, C.H.; Wallsgrove, R. Variation in the glucosinolate content of oilseed rape (Brassica napus L.) leaves. Ann. Appl. Biol. 1991, 118, 469-477. [CrossRef]

51. Ludwig-Müller, J.; Bennett, R.; Kiddle, G.; Ihmig, S.; Ruppel, M.; Hilgenberg, W. The host range of Plasmodiophora brassicae and its relationship to endogenous glucosinolate content. New Phytol. 1999, 141, 443-458. [CrossRef]

52. Brader, G.; Mikkelsen, M.D.; Halkier, B.A.; Tapio Palva, E. Altering glucosinolate profiles modulates disease resistance in plants. Plant J. 2006, 46, 758-767. [CrossRef] [PubMed]

53. Sanchez-Vallet, A.; Ramos, B.; Bednarek, P.; López, G.; Piślewska-Bednarek, M.; Schulze-Lefert, P.; Molina, A. Tryptophan-derived secondary metabolites in Arabidopsis thaliana confer non-host resistance to necrotrophic Plectosphaerella cucumerina fungi. Plant J. 2010, 63, 115-127. [CrossRef]

54. Buxdorf, K.; Yaffe, H.; Barda, O.; Levy, M. The effects of glucosinolates and their breakdown products on necrotrophic fungi. PLoS ONE 2013, 8. [CrossRef]

55. Bednarek, P.; Piślewska-Bednarek, M.; Svatoš, A.; Schneider, B.; Doubský, J.; Mansurova, M.; Humphry, M.; Consonni, C.; Panstruga, R.; Sanchez-Vallet, A.; et al. A glucosinolate metabolism pathway in living plant cells mediates broad-spectrum antifungal defense. Science 2009, 323, 101-106. [CrossRef] [PubMed]

56. Hiruma, K.; Fukunaga, S.; Bednarek, P.; Piślewska-Bednarek, M.; Watanabe, S.; Narusaka, Y.; Shirasu, K.; Takano, Y. Glutathione and tryptophan metabolism are required for Arabidopsis immunity during the hypersensitive response to hemibiotrophs. Proc. Natl. Acad. Sci. USA 2013, 110, 9589-9594. [CrossRef] [PubMed]

57. Yi, G.-E.; Robin, A.H.K.; Yang, K.; Park, J.-I.; Hwang, B.H.; Nou, I.-S. Exogenous methyl jasmonate and salicylic acid induce subspecies-specific patterns of glucosinolate accumulation and gene expression in Brassica oleracea L. Molecules 2016, 21, 1417. [CrossRef] [PubMed] 
58. Zhang, B.; Hu, Z.; Zhang, Y.; Li, Y.; Zhou, S.; Chen, G. A putative functional myb transcription factor induced by low temperature regulates anthocyanin biosynthesis in purple kale (brassica oleracea var. Acephala $\mathrm{f}$. Tricolor). Plant Cell Rep. 2012, 31, 281-289. [CrossRef] [PubMed]

59. Frerigmann, H.; Piślewska-Bednarek, M.; Sánchez-Vallet, A.; Molina, A.; Glawischnig, E.; Gigolashvili, T.; Bednarek, P. Regulation of pathogen-triggered tryptophan metabolism in Arabidopsis thaliana by MYB transcription factors and indole glucosinolate conversion products. Mol. Plant 2016, 9, 682-695. [CrossRef]

60. Wu, J.; Zhao, Q.; Yang, Q.; Liu, H.; Li, Q.; Yi, X.; Cheng, Y.; Guo, L.; Fan, C.; Zhou, Y. Comparative transcriptomic analysis uncovers the complex genetic network for resistance to Sclerotinia sclerotiorum in Brassica napus. Sci. Rep. 2016, 6, 1-15. [CrossRef]

61. Gigolashvili, T.; Yatusevich, R.; Berger, B.; Müller, C.; Flügge, U.I. The R2R3-MYB transcription factor HAG1/MYB28 is a regulator of methionine-derived glucosinolate biosynthesis in Arabidopsis thaliana. Plant J. 2007, 51, 247-261. [CrossRef]

62. Frerigmann, H.; Gigolashvili, T. MYB34, MYB51, and MYB122 distinctly regulate indolic glucosinolate biosynthesis in Arabidopsis thaliana. Mol. Plant 2014, 7, 814-828. [CrossRef] [PubMed]

63. Yang, B.; Rahman, M.H.; Liang, Y.; Shah, S.; Kav, N.N. Characterization of defense signaling pathways of Brassica napus and Brassica carinata in response to Sclerotinia sclerotiorum challenge. Plant Mol. Biol. Rep. 2010, 28, 253-263. [CrossRef]

64. Sticher, L.; Mauch-Mani, B.; Métraux, J.P. Systemic acquired resistance. Ann. Rev. Phytopathol. 1997, 35, 235-270. [CrossRef] [PubMed]

65. Durrant, W.E.; Dong, X. Systemic acquired resistance. Annu. Rev. Phytopathol. 2004, 42, 185-209. [CrossRef] [PubMed]

66. Grant, M.; Lamb, C. Systemic immunity. Curr. Opin. Plant Biol. 2006, 9, 414-420. [CrossRef] [PubMed]

67. Alkooranee, J.T.; Aledan, T.R.; Xiang, J.; Lu, G.; Li, M. Induced systemic resistance in two genotypes of Brassica napus (AACC) and Raphanus oleracea (RRCC) by Trichoderma isolates against Sclerotinia sclerotiorum. Am. J. Plant Sci. 2015, 6, 1662. [CrossRef]

68. Alkooranee, J.T.; Yin, Y.; Aledan, T.R.; Jiang, Y.; Lu, G.; Wu, J.; Li, M. Systemic resistance to powdery mildew in Brassica napus (aacc) and Raphanus alboglabra (rrcc) by Trichoderma harzianum th12. PLoS ONE 2015, 10, e0142177. [CrossRef]

69. Sotelo, T.; Velasco, P.; Soengas, P.; Rodríguez, V.M.; Cartea, M.E. Modification of leaf glucosinolate contents in Brassica oleracea by divergent selection and effect on expression of genes controlling glucosinolate pathway. Front. Plant Sci. 2016, 7, 1-12. [CrossRef]

70. Mithen, R.F.; Lewis, B.G.; Fenwick, G.R. In vitro activity of glucosinolates and their products against Leptosphaeria maculans. Trans. Br. Mycol. Soc. 1986, 87, 433-440. [CrossRef]

71. Xu, L.; Yang, H.; Ren, L.; Chen, W.; Liu, L.; Liu, F.; Zeng, L.; Yan, R.; Chen, K.; Fang, X. Jasmonic acid-mediated aliphatic glucosinolate metabolism is involved in clubroot disease development in Brassica napus L. Front. Plant Sci. 2018, 9. [CrossRef]

72. Harikrishnan, R.; Del Río, L. Influence of temperature, relative humidity, ascospore concentration, and length of drying of colonized dry bean flowers on white mold development. Plant Dis. 2006, 90, 946-950. [CrossRef]

73. Godoy, G.; Steadman, J.; Dickman, M.; Dam, R. Use of mutants to demonstrate the role of oxalic acid in pathogenicity of Sclerotinia sclerotiorum on Phaseolus vulgaris. Physiol. Mol. Plant Pathol. 1990, 37, 179-191. [CrossRef]

74. Zhao, J.; Meng, J. Genetic analysis of loci associated with partial resistance to Sclerotinia sclerotiorum in rapeseed (Brassica napus L.). Theor. Appl. Genet. 2003, 106, 759-764. [CrossRef] [PubMed]

75. Yu, B.; Liu, P.; Hong, D.; He, Q.; Yang, G. Improvement of Sclerotinia resistance of a polima cms restorer line of rapeseed via phenotypic selection, marker-assisted background selection and microspore culture. Plant Breeding 2010, 129, 39-44. [CrossRef]

76. Yi, G.-E.; Robin, A.H.K.; Yang, K.; Park, J.-I.; Kang, J.-G.; Yang, T.-J.; Nou, I.-S. Identification and expression analysis of glucosinolate biosynthetic genes and estimation of glucosinolate contents in edible organs of Brassica oleracea subspecies. Molecules 2015, 20, 13089-13111. [CrossRef] [PubMed]

77. Laila, R.; Robin, A.H.K.; Yang, K.; Park, J.-I.; Suh, M.C.; Kim, J.; Nou, I.-S. Developmental and genotypic variation in leaf wax content and composition, and in expression of wax biosynthetic genes in Brassica oleracea var. Capitata. Front. Plant Sci. 2017, 7, 1972. [CrossRef] [PubMed] 
78. Livak, K.J.; Schmittgen, T.D. Analysis of relative gene expression data using real-time quantitative PCR and the 2- $\delta \delta$ ct method. Methods 2001, 25, 402-408. [CrossRef] [PubMed]

79. Liu, S.; Liu, Y.; Yang, X.; Tong, C.; Edwards, D.; Parkin, I.A.; Zhao, M.; Ma, J.; Yu, J.; Huang, S. The Brassica oleracea genome reveals the asymmetrical evolution of polyploid genomes. Nat. Commun. 2014, 5, 3930. [CrossRef] [PubMed]

80. Seo, M.-S.; Kim, J.S. Understanding of $M Y B$ transcription factors involved in glucosinolate biosynthesis in Brassicaceae. Molecules 2017, 22, 1549. 